University of Northern lowa

UNI ScholarWorks

Faculty Publications

Faculty Work

1999

\title{
The Role of Artists in Ship Camouflage during World War I
}

Roy R. Behrens

University of Northern lowa

Let us know how access to this document benefits you

Copyright (C)1999 The MIT Press

Follow this and additional works at: https://scholarworks.uni.edu/art_facpub

Part of the Art and Design Commons

\section{Recommended Citation}

Behrens, Roy R., "The Role of Artists in Ship Camouflage during World War I" (1999). Faculty Publications. 3.

https://scholarworks.uni.edu/art_facpub/3

This Article is brought to you for free and open access by the Faculty Work at UNI ScholarWorks. It has been accepted for inclusion in Faculty Publications by an authorized administrator of UNI ScholarWorks. For more information, please contact scholarworks@uni.edu. 


\title{
The Role of Artists in Ship Camouflage During World War I
}

\author{
Roy R. Behrens
}

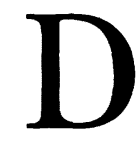

uring World War I, in a 10-month period from March to December 1917, German submarines (called "U-boats" for Unterseeboot, or "under-the-sea boat") sank an average of more than 23 British ships each week for a total of 925 ships. The worst period was in mid-April, when 55 British ships were destroyed in one week, for an average of almost eight ships per day [1].

When a U-boat attacked an enemy ship, one of three methods was commonly used. First, the submarine might remain submerged and, aiming through a periscope from a safe distance, fire an expensive and often inaccurate torpedo. Second, the submarine might come to the surface (which left it vulnerable) and, after allowing some time for preparation, attack with the cannon mounted on its deck. Third, if its target was an unarmed merchant ship, the submarine might come to the surface, move alongside the captured ship, remove everyone on board and then sink the empty ship by blowing it up.

Prior to World War I, the German Navy preferred the third method. Its official stated policy was that "destruction may not take place before everyone on board has been brought to safety along with their goods and chattels. . . ." In late 1914, however, it adopted a new policy, one which proclaimed that "a U-boat cannot spare the crews of merchant ships, but must send them and their ships to the bottom of the sea. All shipping should be warned and all merchant shipping to England should be brought to a halt in a short period of time" [2].

In the early years of the war, this new policy was not strictly carried out, because many of the merchant ships (often clandestinely carrying goods to aid England's war effort) were coming from the United States, which was a neutral power that Germany would have preferred not to offend. However, a more severe policy was introduced in January 1917 when Germany announced that its submarine warfare would be unrestricted. From then on, all ships traveling within a certain war zone, even ships from neutral countries, if suspected of transporting aid to England, would be attacked by Uboats. Four months later, this policy resulted in the sinking of the Lusitania, a British passenger ship, in which 1,195 passengers were killed, including 128 U.S. citizens. The American public was outraged by the tragedy, and it was later a major contributor to the U.S. decision to enter the war on the side of the Allies.

One reason for Germany's more severe policy toward ships of neutral countries was England's decision to use mimicry in its camouflage, resulting in ships of questionable identity called "Q-Ships." These were armed British ships disguised as unarmed merchant ships. They often flew "false colors," erroneous flags of neutral countries, in the hope of enticing a U-boat to come to surface and to move in, at which time the guns of the British decoy would be unveiled and the submarine fired on at close range. While this strategy was moderately successful for a while, the element of surprise was soon lost, and the U-boats became increasingly cautious about approaching merchant ships, even those with neutral flags. For this and other reasons, Uboats began to attack with torpedoes, while remaining submerged and aiming through a periscope from a distance of at least 2,700 yards, or about $1^{1 / 2}$ miles [3].

\section{DAZzLe PAINTING}

Accordingly, as the toll of the U-boats continued to mount, the chief concern of Allied ships was how to avoid a torpedo attack. This problem was addressed in the early months of 1917 by a 39-year-old British illustrator, marine painter and designer named Norman Wilkinson, who was a lieutenant in the Royal Navy. Years later, Wilkinson recalled the time and exact circumstances that led to his invention of "dazzle painting":

\begin{abstract}
On my way back to Devonport in the early morning, in an extremely cold carriage, I suddenly got the idea that since it was impossible to paint a ship so that she could not be seen by a submarine, the extreme opposite was the answer-in other words, to paint her, not for low visibility, but in such a way as to break up her form and thus confuse a submarine officer as to the course on which she was heading [4].
\end{abstract}

Wilkinson concluded that prior attempts at ship camouflage had been ineffective because techniques used for ground camouflage had been used inappropriately for ships. In ground camouflage, the object to be camouflaged is often stationary, and one is more or less assured of a fixed and predictable background. In naval camouflage, however, the object to be camouflaged is nearly always moving, and its background is frequently shifting as well. Further, even if a ship were stationary, its two predominant backgrounds-the sea and the sky-are constantly changing in color and light.

Roy R. Behrens (artist, writer, teacher), 2022 X Avenue, Dysart, IA 52224-9767, U.S.A. E-mail: <ballast@netins.net>. 


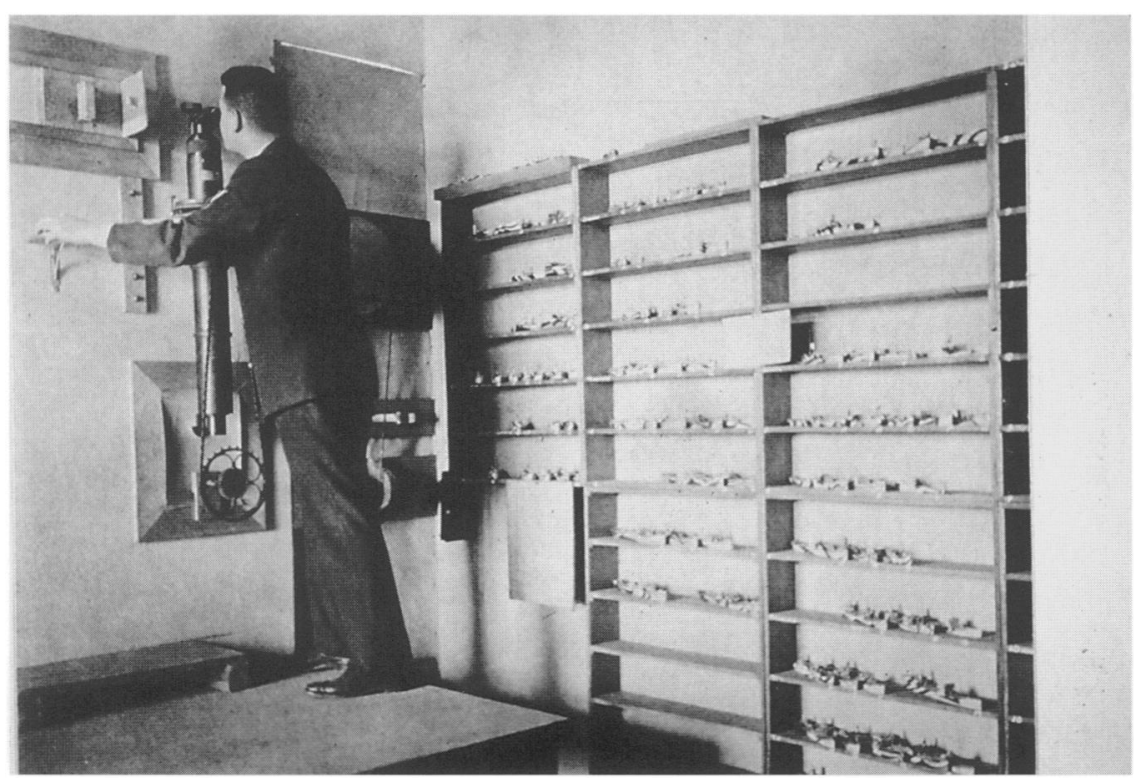

Fig. 1. Following the example of their British counterparts, the American naval camouflage artists tested their painted ship models by observing them through a periscope in a theater that simulated the lighting conditions and point of view of a submarine. (Photo: U.S. Navy Department, National Archives and Record Service)

Given these and other variables, thought Wilkinson, it was absurd to attempt to conceal a ship on the ocean. Since invisibility was impossible in naval camouflage, it would be more effective to paint erratic patterns on the ship's surface, making it even more visible, and thereby confuse, or "dazzle," the submarine gunner so that he could not be sure about the target's course, size, speed or distance. The primary goal was to confuse the U-boat gunner about what position to fire from when the ship was first sighted. A submarine, explained Wilkinson, "having once failed to obtain a good position has little or no likelihood of regaining that position, owing to insufficient underwater speed" [5]. And even if the submarine did get into firing position, the bewildering pattern might still spoil the gunner's aim. This was possible because a gunner did not aim the torpedo at a ship, but rather fired it ahead of the ship-it had to lead its target-so that quickly and accurately determining the course of the ship was absolutely essential.

When Wilkinson submitted his idea to the British Admiralty, it was initially ignored. Soon, however, it was taken seriously, with the result that the H.M.S. Industry, a small store ship, was ordered to be painted in an experimental dazzle scheme under Wilkinson's supervision. Meanwhile, other British ships, the coast guard and shore stations were instructed to report their impressions whenever they sighted the curious boat. design the dazzle schemes; three ship

A few days later, the British Admiralty ordered 50 troopships to be dazzlepiled immediately, and Wilkinson Dazzle Section. Located in a spare classroom at Burlington House, home of the Royal Academy of Arts, this unit consisted of 17 workers: Wilkinson; five male artists (either unfit or too old for military service) chosen by Wilkinson to model-makers (two male, one female); and 11 young female art students, who prepared hand-colored mechanical drawings that were used in painting the actual ships [6].

In addition, 10 other men were appointed dock officers at various harbors around Britain, including Bristol, Liverpool, Newcastle and Glasgow. Initially, these men only supervised the painting of the ships, but later, when generic schemes were used on ships of varying sizes and shapes, they also contributed to modifying the dazzle schemes. One of these officers was Edward Wadsworth, a painter who played a significant role before World War I in the development of Vorticism, a British combination of Cubism and Futurism [7].

In Wilkinson's words, the ships were prepared in the following way:

In the initial stages a small wooden model of each ship was made to scale. On this a design was painted in wash colors for the purposes of rapid alteration. This model was then carefully studied on a prepared theatre through a submarine periscope, various sky backgrounds being placed behind her alternately. A satisfactory design having been evolved giving the maximum distortion, the model was then handed to the trained plan maker and copied on to a $1 / 16$ th-inch scale profile plan of the ship on white paper showing port and starboard side. The plan was then sent to the outport officer at the port at which the particular ship was lying and transferred under his supervision to the ship [8].
Fig. 2. Four members of the American naval camouflage unit, circa 1918, under the direction of Everett L. Warner (not shown), at work applying dazzle schemes to miniature wooden ship models. Second from the right is the American painter Frederic Waugh. (Photo: U.S. Navy Department, National Archives and Record Service)

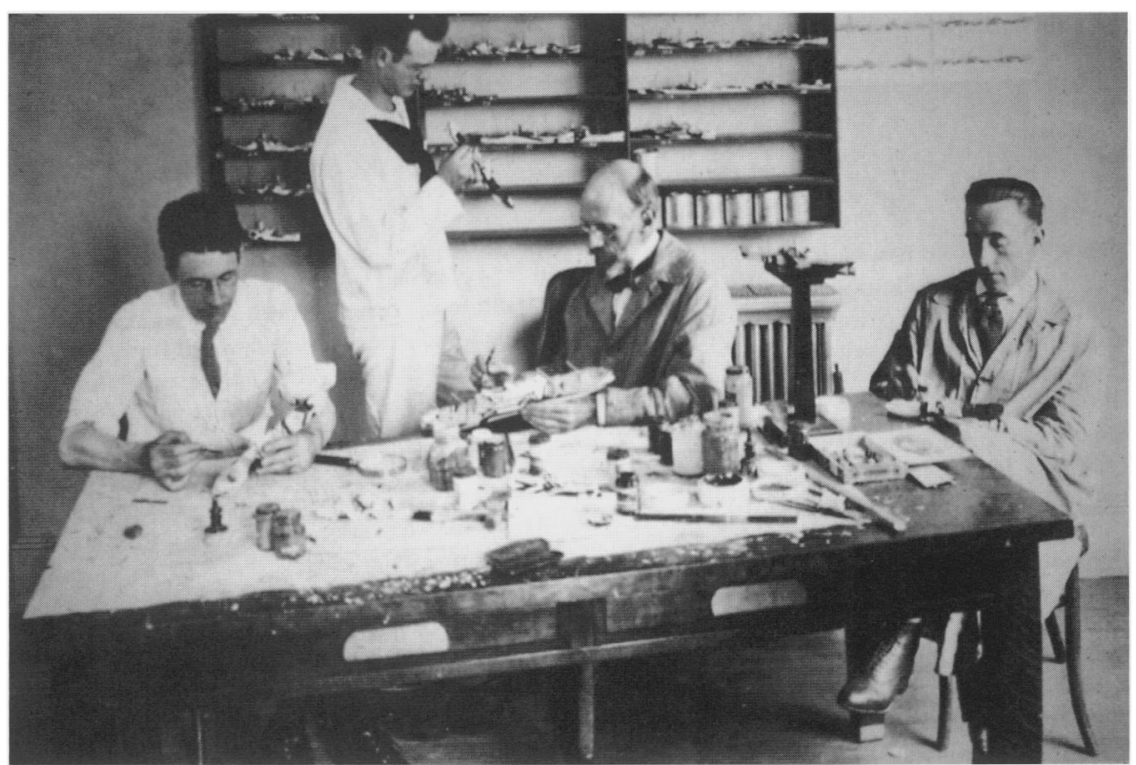




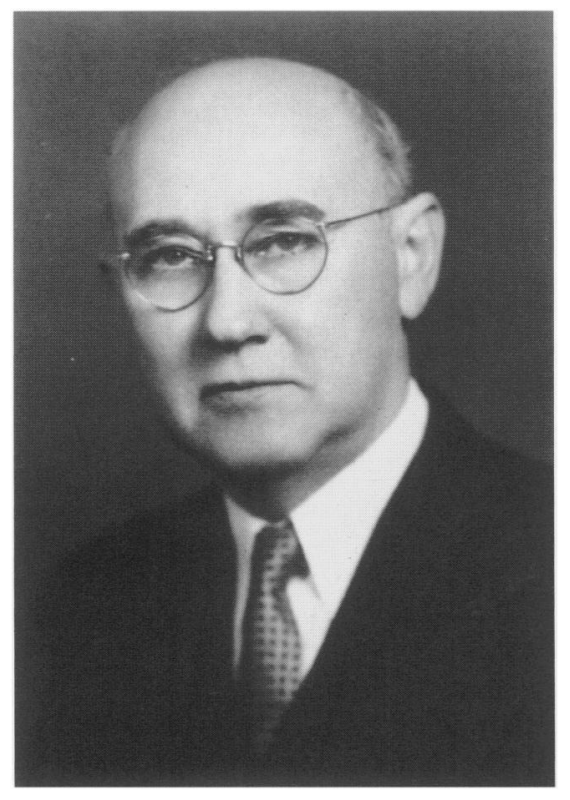

Fig. 3. U.S. artist Everett L. Warner (18771963), a major contributor to the development of U.S. ship camouflage during both world wars. (Photo: Carnegie Mellon University Archives)

Each of the first 50 dazzle-painting schemes was unique, in the sense that a different design was applied to each ship. Further, on any one ship, the design on the port side was different from that on the starboard. As before, observers were asked to report what they saw when dazzle-painted ships were sighted. One was described as "almost impossible to say how she was steering," while it was said of another that it "sometimes appears to be going in the opposite direction" [9]. As a consequence, in October 1917, the Admiralty decided that dazzle camouflage should be applied to all armed and unarmed merchant ships, so that by the end of the following June, more than 2,300 British ships had been dazzle-painted. There were moments when as many as 100 ships were being dazzle-painted in a single harbor at one time.

\section{AMERICAN SHIP CAMOUFLAGE}

In the meantime, as a result of a visit to England by Admiral William S. Sims of the U.S. Navy, the U.S. government requested that Wilkinson be loaned to the United States. This request was submitted in spite of the fact that six camouflage methods had already been adopted by the U.S. Navy. One of these, called the "Brush System," was patented by U.S. artists Abbott H. Thayer and Gerome Brush, and was based on the former's discovery of "countershading" in animals in 1892. Inspired by the coloration of sea gulls, it required the upper portions of a ship, which are normally in sunlight, to be painted gray, while portions most likely to be in shadow would be painted pure white [10]. Another was the "Mackay System," a low-visibility pointillist plan invented by New York artist William Andrew Mackay, which was based on the notion that gray would result when certain patches of color were seen from a distance [11]. A third, known as the "Warner System," proposed by Iowaborn artist and naval officer Everett Warner, was, like Wilkinson's method, designed to interfere with range finding [12]. Other systems were developed by Maximilian Toch (an authority on paint chemistry), Lewis Herzog and a person named Watson [13].

Encouraged by the Board of Marine Insurance Underwriters, which offered preferred insurance rates to camouflaged merchant ships, dozens of other suggestions were made by U.S. artists, inventors and patriotic amateurs throughout the country. Thayer submitted two models, one in which the ship was draped by an enormous net and another in which it was covered by "a huge spread of canvas painted to imitate a cloud" [14]. In a proposal from Thomas Edison, an entire ship was apparently disguised as an island, complete with a lighthouse and pine trees. Thayer's proposals were rejected outright, but because of Edison's prestige, his scheme was actually applied to the S.S. Ochenfels; however, but his camouflage made the ship "so unseaworthy that it [the imitation island] got carried away before the vessel got out of New York Harbor" [15]. A number of people suggested that ships be nickelplated or completely covered in mirrors. Others proposed that they be disguised to look like whales or icebergs [16].

Wilkinson sailed to America in March 1918 on the Leviathan, formerly the Vaterland, a large ocean liner captured from Germany by the United States, then converted for use as a troopship. Arriving in New York, Wilkinson was taken to Washington, D.C., to a meeting with Franklin D. Roosevelt, then Assistant Secretary of the Navy, who expressed his admiration for dazzle painting. "We have no department of camouflage here," Roosevelt said,

Up to the present ship camouflage in the United States has been carried out by a number of private individuals, all of whose systems vary, but are mainly in the
Fig. 4. U.S. marine painter and ship camouflage artist Frederic Waugh (1861-1940). (Photo: Peter A. Juley and Paul Juley [37])

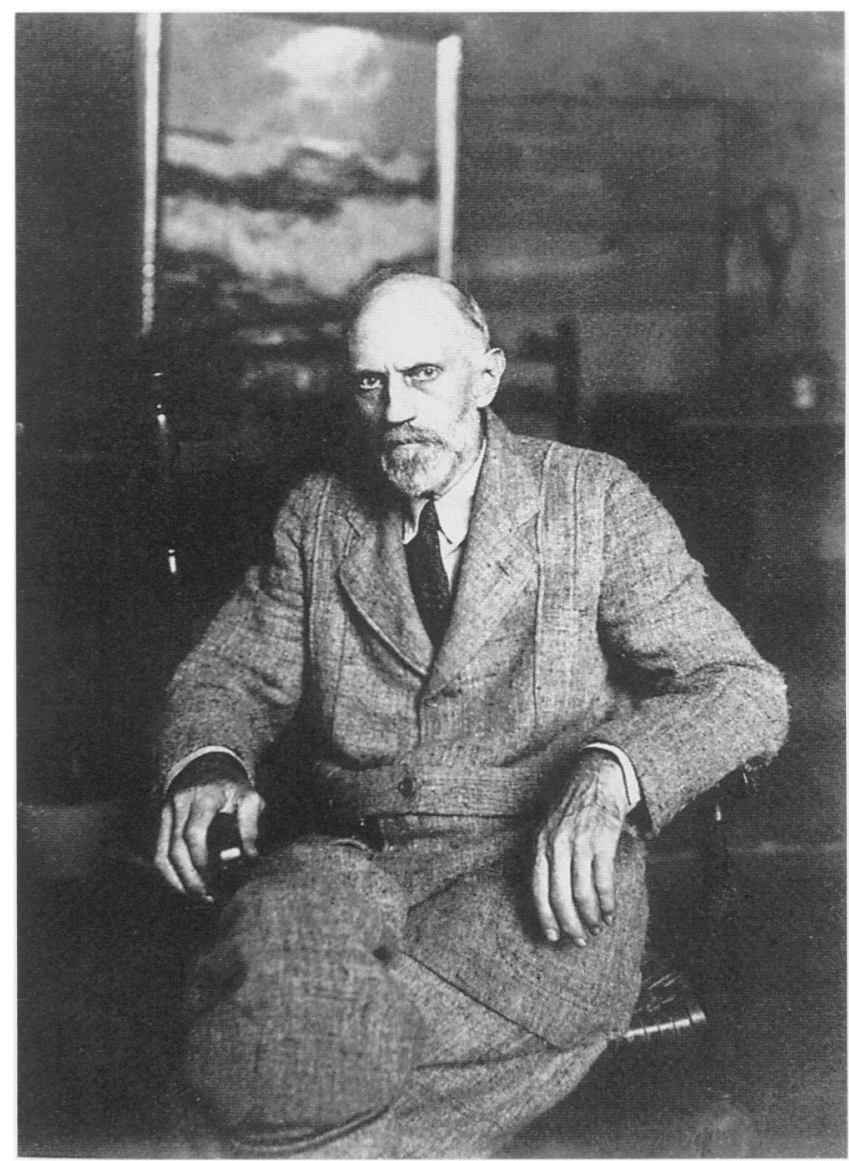




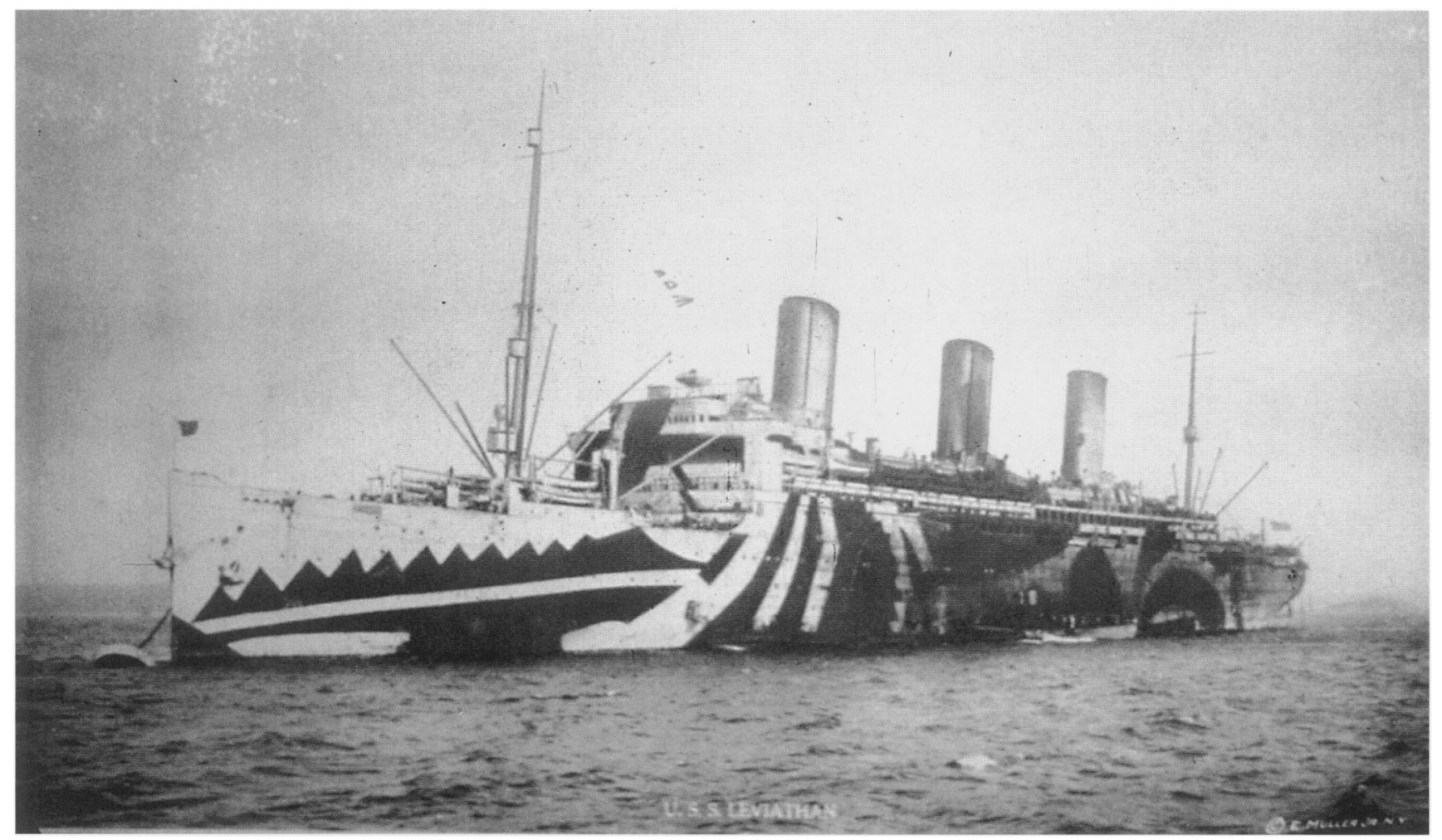

Fig. 5. Dazzle camouflage scheme designed by Frederic Waugh, circa 1918, for application to an American troop ship, the Leviathan, which was a captured German passenger liner formerly known as the Vaterland. Photographs like this were withheld from publication until after World War I to prevent the German Navy from learning about Allied camouflage designs. (Collection of Roy R. Behrens)

order of invisibility or low-visibility treatment. They have been selling their plans at so many dollars a foot run to ship owners. We had no means of testing the results in a practical way. ... [17]

During the next 4 weeks, Wilkinson assisted in organizing an American Camouflage Section, patterned after its British predecessor and established as part of the Bureau of Construction and Repair. Lieutenant Harold Van Buskirk was placed in charge of the unit, and two subdivisions were set up. The research subdivision at the Eastman Kodak Company in Rochester, New York, was comprised of scientists; the design subdivision in Washington was made up of artists [18].

The person in charge of the research group in Rochester was Lieutenant Loyd A. Jones, who was head of the physics laboratory at Eastman Kodak. As a civilian, Jones had already contributed to the efforts of the Submarine Defense Association by inventing a "visibility meter," a device to measure how visible an object is in an ocean setting. Later, he set up a theater for studying camouflaged ship models (Fig. 1) in which a periscope used to view the models moved on a track and the lighting was much more elaborate than had been used before [19].
The artist in charge of the Washington subdivision was Lieutenant Warner (Figs 2 and 3), who escorted Wilkinson as he lectured at harbors in Boston, New York, Philadelphia and Norfolk on the purpose, design and application of dazzle painting [20]. Back in Washington, Warner assembled a small team of camouflage artists, including marine painter Frederic Waugh (Fig. 4) (who produced the especially wonderful plan for dazzle-painting the Leviathan, shown in Fig. 5), portrait painter Gordon Stevenson, sculptor John Gregory, Kenneth MacIntire, A. O'Connell and a person named Richardson [21]. Like their British counterparts, they applied dazzle patterns to miniature wooden models, tested the models in a periscopeequipped theater and prepared instructions for painting the ships.

In the meantime, official approval was withdrawn from all naval camouflage systems other than dazzle painting. It became the sole responsibility of Warner's team of artists to camouflage all American ships, while the Shipping Board provided camoufleurs (camouflage experts) at ports (most of whom were professional artists and architects) who supervised the painting. In addition, the Office of Naval Intelligence used artists and photographers to make color sketches and photographs for Warner's team of camouflaged ships in American ports. One of the artists assigned to draw ships was Louis Bouché [22]. Another was Thomas Hart Benton, who wrote in a letter that "This is done so that if the ship should be torpedoed or lost in any way all the facts concerning her appearance etc. can easily be found" [23].

But there were other reasons for making the drawings. It was, for example, of value to have drawings and photographs of camouflaged foreign ships to compare and contrast to U.S. schemes. In addition, by studying drawings and paintings of ships, the camouflage artists could determine if the camouflage schemes had been correctly applied. As it turned out, often they had not, especially when the Shipping Board camoufleurs were asked to use a single scheme for several ships, each structurally different. In many cases, it was evident that the camoufleur had failed to understand the underlying principles, so much so that finally it was arranged that each week three Shipping Board camoufleurs would travel to Washington for a brief but intensive workshop on dazzle painting.

During the final 8 months of World War I, more than 1,200 American ships 
were painted with dazzle schemes produced by the Washington subdivision, about half of which were modifications of British designs. Hundreds of others were totally new, and some were considerably different from those produced by Wilkinson's group. The difference was largely the consequence of an ingenious method (Fig. 6), devised by Warner, using anamorphosis, in which new dazzle patterns were invented by arranging color wooden blocks (many in reversed perspective) at an oblique angle against the side of a ship model, then converting that arrangement to a flat pattern [24].

The results of dazzle painting were astonishing. "Those who were not fortunate to see the docks at one of our great ports during the war," a writer recalled,

may imagine the arrival of a convoyor, as frequently occurred, two at a time-of these painted ships, and the many miles of docks crowded with vessels of all sorts . . . each resplendent with a variety of bright-hued patterns, up-to-date designs of stripes in black and white or pale blue and deep ultramarine, and earlier designs of curves, patches, and semicircles. Take all these, huddle them together in what appears to be hopeless confusion, but which in reality is perfect order, bow and stern pointing in all directions, mix a little sunshine, add the varied and sparkling reflections, stir the hotchpotch up with smoke, life, and incessant movement, and it can safely be said that the word "dazzle" is not far from the mark [25].

Riding in a convoy of dazzle-painted ships, a journalist said, was "like being in the middle of a floating art museum," while others spoke of dazzled ships as "so many floating cubist paintings," "a futurist's bad dream," "cubist painting on a colossal scale" and "a cross between a boiler explosion and a railroad accident" [26]. "You should see our Fleet!," exclaimed an American newspaper,

It's camouflaged so, it looks like a flock of sea-going Easter Eggs. If you shut your eyes good and tight, and stand behind a wall, you can't see a ship a cable's length away. It was an English guy [Wilkinson] thought of it first, and his name's the first toast now at all the paint-makers' social reunions [27].

But was it Wilkinson who first thought of dazzle painting? Not according to a U.S. naval manual, prepared in 1961, which contended that Thayer devised "a system of course- and type-deception painting which used misleading paintedpatterns to falsify real perspective and natural lines of construction" as early as 1915 (2 years in advance of Wilkinson),

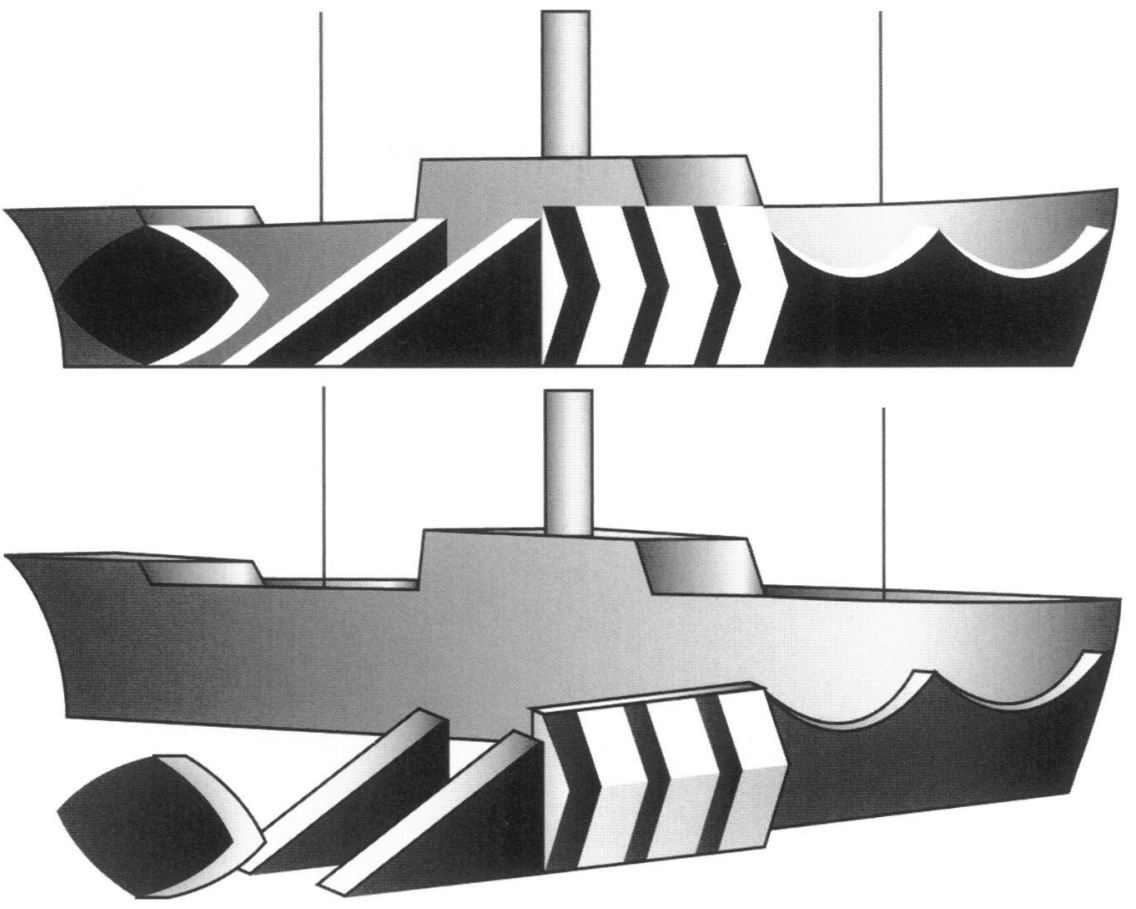

Fig. 6. Drawings made from photographs of a demonstration by Everett L. Warner of a method using anamorphosis to invent dazzle camouflage schemes by arranging colored wooden blocks (many in reversed perspective) at an oblique angle against the side of a ship model, then converting that arrangement to a flat pattern. (Redrawn by Ryan McAdam, from photographs [38])

a system that Thayer discovered while studying ship models on a pond in Dublin, New Hampshire, when "he noticed that a partly painted model appeared to be headed in the wrong direction" [28]. "Such strong contrasting deception patterns," the manual explains, "when carefully designed by good artists, could make a ship appear to be headed on any course desired, regardless of [the] ship's actual course" [29]. Regrettably, no source for the story is given, and no mention of it has been found elsewhere.

Nevertheless, there are portions of Thayer's book, Concealing Coloration in the Animal Kingdom, that may have anticipated dazzle painting [30]. It shows, for example, a photograph of four butterflies (Fig. 7), three with monochromatic coloring (black, white and gray) and one with high-contrast disruptive coloring. In the caption, the reader is instructed to study the photograph from a distance of 7 or 8 yards, at which point the three monochromatic butterflies remain identifiable, while the fourth looks fragmented and incoherent [31].

Looking at this photograph, I am reminded of a letter to the editor in the May 1919 issue of Nature by John Graham Kerr, a Scottish professor of zoology and a Member of Parliament, who had spoken in favor of an earlier attempt by Thayer, assisted by John Singer Sargent, to persuade the British to abandon the monochromatic, khaki field-service uniform in favor of a dazzle-like multi-colored uniform [32]. In this letter, Kerr claimed that Wilkinson's invention of dazzle painting was not unprecedented, and that, as early as 1914 , he had invented a similar scheme, using parti-coloring or disruptive coloring in combination with countershading. He had proposed this system to the British Admiralty at the start of World War I when he became convinced that uniform coloring, whether black, white or monochromatic gray, was ineffective camouflage, even dangerous, in the sense that-like Thayer's photograph of butterflies-it enabled the overall shape to remain clearly readable from a great distance. "I also directed attention," he writes, "to its [multi-coloring's] use in confusing the details, especially vertical lines, which are made use of by the enemy's range finders" [33].

A month later, there was a reply from Wilkinson in the same journal, in which he argued that Kerr "has not thoroughly grasped the idea of the special form of camouflage on which I was engaged, and of which I still claim to be the originator" [34]. Dazzle painting, said 
Wilkinson, was not derived from biological examples. It has little relation to disruptive coloring, in the sense that the latter attempts to decrease visibility, while his system merely confuses the aim of the submarine gunner and may even heighten visibility.

As for countershading, it is simply not practicable in ship camouflage, Wilkinson said, because any design requiring white patches or subtle coloration would soon be ruined by the heat, smoke, fuel and rust that constantly leak from a functioning ship. All ships require repainting every 6 months, and the dazzle-painted ships would appear cleaner and more effective than others, Wilkinson explained later, "on the principle that a white table cloth will look dirty sooner than a patchwork quilt" [35].

Throughout World War I and long afterwards, there were recurring misgivings about the usefulness of dazzle painting. To what extent could Wilkinson's assertions about its effectiveness be verified? U.S. sources claimed that less than $1 \%$ of dazzle-painted ships were sunk by torpedoes. But when the British Admiralty set up a Committee on Dazzle

Fig. 8. Byron Burford, Camouflage, collage, 1996. Since World War I, some artists have continued to be interested in ship camouflage, as demonstrated by its occasional use as subject matter. The creator of this piece (who is also a circus drummer) served in the U.S. Air Corps during World War II. "I tried to get into camouflage," he recalls, "but they needed radio operators at that time. Because I was a drummer, I passed the Morse Code aptitude test $100 \%$. As it turned out, my entire platoon were jazz musicians, for their scores on the aptitude test were all very good. A less military group I never saw" [40].

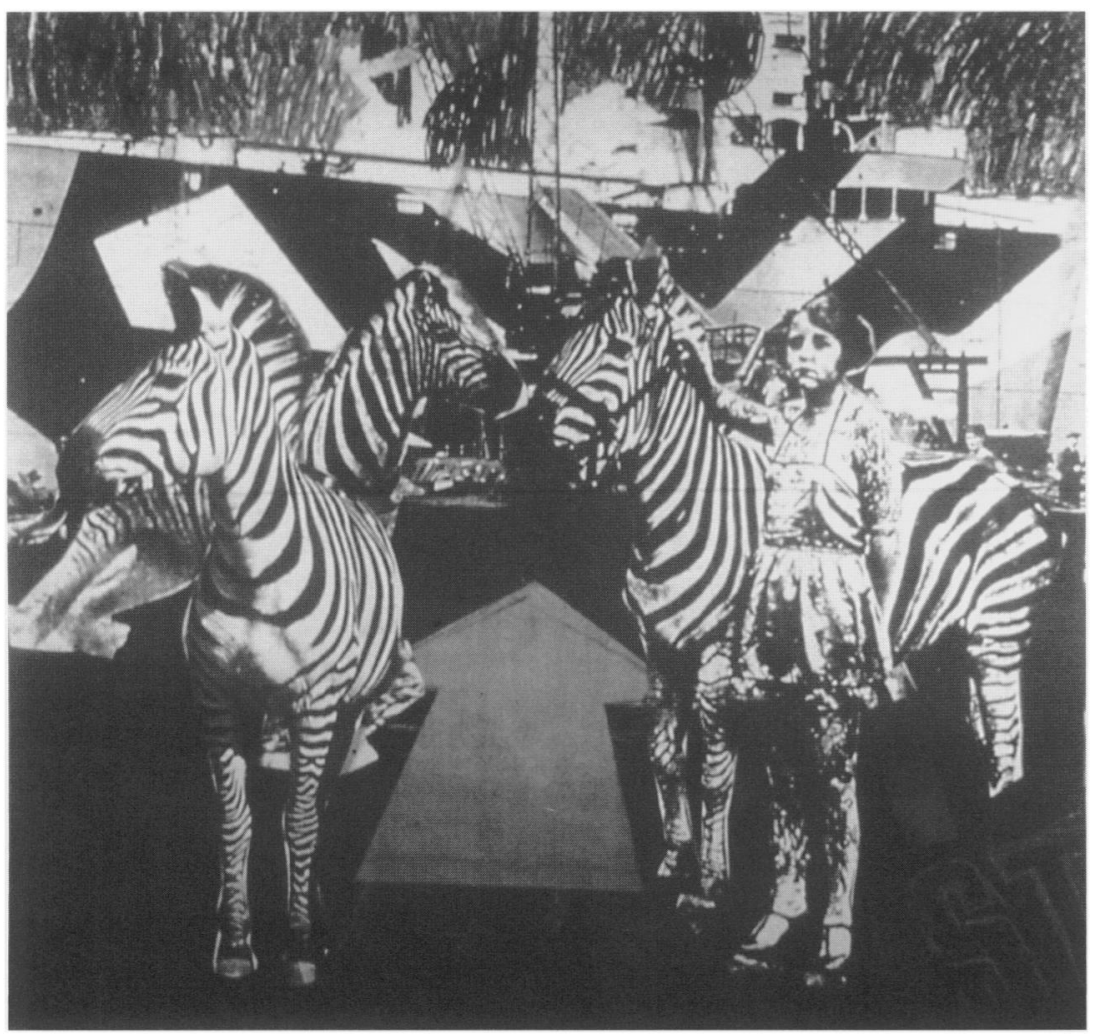

doubted increase" in the confidence and morale of the crew on dazzled-painted ships [36].

World War I ended officially on 28 June 1919, with the signing of the Treaty of Versailles. Partly because ships require periodic repainting, dazzle painting soon disappeared. No longer menaced by German U-boats, the Allied navies chose to paint virtually all their ships in monochromatic gray, instead of expending additional time on the restoration of multi-colored dazzle schemes (Fig. 8 and Color Plate A No. 2).

\section{References and Notes}

1. For background information on the "submarine problem" in relation to ship camouflage, see Matthew Luckiesh, Visual Illusions: Their Causes, Characteristics and Applications (New York: Dover, 1965) pp. 222-233; Guy Hartcup, Camouflage: A History of Concealment and Deception in War (New York: Scribner's, 1980) pp. 35-47; and David Williams, Liners in Battledress: Wartime Camouflage and Colour Schemes for Passenger Ships (St. Catharines, Ontario: Vanwell, 1989).

2. For U-boat methods of attack, see Hartcup [1] p. 36. German Navy attack policies are quoted in a four-page English insert in Albert Roskam, Dazzle Painting: Kunst Als Camouflage: Camouflage Als Kunst, exh. cat. (Rotterdam, The Netherlands: Stichting Kunstprojecten en Uitgevergij Van Spijk, 1987).

3. See Hartcup [1] and Roskam [2]

4. Quoted in Norman Wilkinson, A Brush With Life (London: Seeley Service and Co., Ltd., 1969) p. 79. For other accounts of dazzle painting, see Paul Atterbury, "Dazzle Painting in the First World War," Antique Collector 46, No. 4, 25-29 (1975); Hartcup [1]; Roy R. Behrens, Art and Camouflage: Concealment and Deception in Nature, Art and War (Cedar Falls, IA: North American Review/Univ. of Northern Iowa, 1981), "The Art of Dazzle Painting" Defence Analysis 3, No. 3, 233-243 (1987), "Blend and Dazzle: The Art of Camouflage," Print 45, No. 1, 92-98ff (1991), "Camouflage," in Jane Turner, ed., The Dictionary of Art (London and New York: Grove Dictionaries, 1996), and "Iowa's Contribution to Camouflage," Iowa Heritage Illustrated 78, No. 3 (1997). 
5. Norman Wilkinson, "The Dazzle Painting of Ships" (1919), reprinted in Camouflage, exh. cat. (Edinburgh, Scotland: Scottish Arts Council, 1988), unpaged.

6. Detailed accounts of the British Dazzle Section, with photographs of male and female camoufleurs preparing dazzle-painted ship models at Burlington House, are found in Wilkinson [4] and [5] and Roskam [2].

7. For his daughter's description of Wadsworth's service as an outport officer, see Barbara Wadsworth, Edward Wadsworth: A Painter's Life (Salisbury, UK: Michael Russell Ltd., 1989) pp. 7578. Regarding Vorticism and camouflage, see Richard Cork, Vorticism and Abstract Art (Berkeley, CA: Univ. of California Press, 1976) pp. 520-524, and A Bitter Truth: Avant-Garde Art and the Great War (New Haven, CT: Yale Univ. Press, 1994).

8. Wilkinson [5] unpaged.

\section{Quoted in Wilkinson [4] p. 96}

10. Regarding countershading (or "Thayer's Law") and other contributions to camouflage by Thayer, see Nelson C. White, Abbott H. Thayer: Painter and Naturalist (Hartford, CT: Connecticut Printers, 1951); Ross Anderson, Abbott Handerson Thayer, exh. cat. (Syracuse, NY: Everson Museum, 1982) pp. 113-125; and Roy R. Behrens, "The Theories of Abbott H. Thayer: Father of Camouflage" Leonardo 21, No. 3, 291-296 (1988). Thayer's collaboration with Brush is described by Brush's daughter in Nancy Douglas Bowditch, George de Forest Brush (Peterborough, NH: William L. Bauhan, 1970).

11. The systems adopted prior to Wilkinson's arrival in the United States are described and illustrated in Robert F. Sumrall, "Ship Camouflage (WWI): Deceptive Art," United States Naval Institute Proceedings 97, No. 7, 57-77 (1971); and Williams [1] pp. 151-152.

12. See Everett L. Warner, "The Science of Marine Camouflage Design," Transactions of the Illuminating Engineering Society 14, No. 5, 215-219 (1919).

13. See Maximilian Toch, "Adventures in Camouflage," The Military Engineer 23 (July/August 1931) pp. 307-309; and Maximilian Toch, "Discussion," Transactions of the Illuminating Engineering Society [12] pp. 230-232.

14. Everett L. Warner, quoted in White [10] p. 138.

15. Warner [14] p. 138. Without naming Thayer and Edison, Warner also talks about their proposals in Everett L. Warner, "Fooling the Iron Fish: The Inside Story of Marine Camouflage," Everybody's Magazine (November 1919) pp. 102-109.

16. Warner [15] "Fooling the Iron Fish," pp. 108 109 .

17. Wilkinson [4] pp. 90-91.

18. See Harold Van Buskirk, "Camouflage," Transac tions of the Illuminating Engineering Society [12] pp 225-229.

19. For information on Loyd A. Jones and the Eastman Kodak research laboratory, see Carl W. Ackerman, George Eastman (Boston, MA: Houghton Mifflin, 1930) pp. 310-312, and "A Theatre for Studying Camouflaged Ship Models," Scientific American Supplement, No. 2290 (13 December 1919) pp. 348-349.

20. Wilkinson's visit to the United States is described in Wilkinson [4] pp. 90-92. Regarding that and the organization of the Washington-based Dazzle Section, see Warner [12] and [15].

21. The names have been partly determined from a magazine photograph in Roskam [2], p. 23, on which the names are penciled in, and from the tex in Warner [15]. See also George R. Havens, Frederick J. Waugh: American Marine Painter (Orono, ME: Univ. of Maine Press, 1969) pp. 152-155.

22. Bouché provides a brief account of his camouflage experiences in unpublished autobiographical notes, available on microfilm (rolls 688-689) from the Archives of American Art.

23. For descriptions of Benton's experience, see Cork, A Bitter Truth [7] p. 193; and Henry Adams, Thomas Hart Benton: An American Original (New York: Alfred A. Knopf, 1989) p. 86

24. Anamorphosis was first described by Leonardo da Vinci circa 1485. In its artistic uses, a painted image appears distorted when viewed from the front, as is customary, but corrects when the image is viewed from the side. As described in Roy $R$. Behrens, "The Life and Unusual Ideas of Adelber Ames, Jr.," Leonardo 20, No. 3, 273-279 (1987), and "Adelbert Ames and the Cockeyed Room," Print 48 No. 2, 92-97 (1994), among the most famous examples of anamorphosis is the Ames Distorted Room (invented in 1935), which has an oblique rear wall, and in which an odd, misshapen room appears normal from a single, designated viewing point. Warner's method of producing dazzle schemes, using colored blocks placed at oblique angles (as described in detail in Warner [12] and $[15]$ ), is a variation on the same principle, al- though, like Ames, he does not use the formal term "anamorphosis." Indeed, in Warner [12] p. 218, he even proposes distorting the appearance of a normal room by making its wallpaper seem to exist on an oblique plane.

25. Hugh Hurst, "Dazzle-Painting in War-Time," International Studio (September 1919) pp. 93-97.

26. Quoted in Roskam [2]; Charles DeKay, "Ships That Fade Away," Nation (27 July 1918) p. 105, and "Camouflage," Time (25 September 1939) p. 42.

27. Quoted in Wilkinson [4] p. 92.

28. D.R.E. Brown, Ships Concealment Camouflage In structions (Washington, D.C.: Bureau of Ships, U.S Navy Department, 1963) p. 2.

29. Brown [28]

30. Gerald H. Thayer, Concealing Coloration in the Animal Kingdom: An Exposition of the Laws of Disguise Through Color and Pattern: Being a Summary of Abbot H. Thayer's Disclosures (New York: Macmillan, 1909; 2nd Ed., 1918).

31. Thayer [30] Fig. 106, unpaged, following p. 152

32. John Graham Kerr, "Letters to the Editor: 'Camouflage' of Ships in War," Nature 103, No. 2585 204-205 (1919).

33. Kerr [32] p. 205

34. Norman Wilkinson, "Letters to the Editor: Camouflage of Ships in War," Nature [32] pp. 304-305.

35. Wilkinson [5], unpaged.

36. Quoted in Roskam [2], unpaged insert.

37. As reproduced in Joan Stahl, compiler, American Artists in Photographic Portraits: From the Peter A. Juley and Son Collection, National Museum of American Art Smithsonian Institution (Mineola, NY: Dover, 1995).

38. See Luckiesh [1] p. 229.

39. From Thayer [30], image following p. 152.

40. Byron Burford, in a letter to the author dated 26 August 1998.

Manuscript received 25 March 1997 